The Canadian Mineralogist

Vol. 38, pp. 669-674 (2000)

\title{
THE CRYSTAL CHEMISTRY OF POTASSIC-FERRISADANAGAITE
}

\author{
ELENA V. SOKOLOVA AND FRANK C. HAWTHORNE $^{\S}$ \\ Department of Geological Sciences, University of Manitoba, Winnipeg, Manitoba R3T 2N2, Canada \\ YURI K. KABALOV \\ Department of Crystallography, Faculty of Geology, Moscow State University, Moscow, 119899, Russia
}

JULIUS SCHNEIDER

Institut für Kristallographie, Universität München, D-80333 München, Germany

\section{CATHERINE MCCAMMON}

Bayerisches Geoinstitut, Universität Bayreuth, D-95440 Bayreuth, Germany

\begin{abstract}
The crystal structure of potassic-ferrisadanagaite, $\left(\mathrm{K}_{0.66} \mathrm{Na}_{0.32}\right)_{\Sigma 0.98}\left(\mathrm{Ca}_{1.73} \mathrm{Na}_{0.23} \mathrm{Mn}_{0.04}\right)_{\Sigma 2.00}\left(\mathrm{Mg}_{0.55} \mathrm{Fe}^{2+}{ }_{2.16} \mathrm{Mn}_{0.25} \mathrm{Fe}^{3+}{ }_{1.11}\right.$ $\left.\mathrm{Al}_{0.78} \mathrm{Ti}_{0.19}\right)_{\Sigma 5.00}\left(\mathrm{Si}_{5.33} \mathrm{Al}_{2.67}\right)_{\Sigma 8.00} \mathrm{O}_{22}\left[(\mathrm{OH})_{1.21} \mathrm{~F}_{0.41} \mathrm{O}_{0.38}\right]_{\Sigma 2.00}, a$ 9.9309(1), b 18.0949(3), c 5.3681(1) $\AA, \beta$ 105.19(2),$V 930.9(1)$ $\AA^{3}, C 2 / m, Z=2, D($ calc $)=3.36 \mathrm{~g} / \mathrm{cm}^{3}$, has been refined using the Rietveld method to the following values: $R_{\mathrm{p}}=3.5, R_{\mathrm{B}}=2.6 \%$. Mössbauer spectroscopy was used to characterize the $\mathrm{Fe}^{3+} /\left(\mathrm{Fe}^{2+}+\mathrm{Fe}^{3+}\right)$ value, and site populations were assigned on the basis of the refined site-scattering values at the $A-, B$-, and $C$-group sites, the unit formula calculated from the results of the chemical analysis, and the observed mean bond-lengths. The $T(1)$ site is approximately half-occupied by ${ }^{[4]} \mathrm{Al}(2.15$ apfu: atoms per formula unit) and the $T(2)$ site is significantly occupied by ${ }^{[4]} \mathrm{Al}(0.66$ apfu according to the $\langle T(2)-\mathrm{O}\rangle$ distance $)$. This distribution is in accord with no ${ }^{T} \mathrm{Al}-\mathrm{O}-{ }^{T} \mathrm{Al}$ linkages in the structure (in accord with the absence of $\mathrm{Ca}$ at the $A$ site). In the presence of large amounts of ${ }^{T} \mathrm{Al}$ ( > 2 apfu), linkage between the octahedron strip and the double-chain of tetrahedra is maintained by incorporation of large cations at the $M(1), M(2)$ and $M(3)$ sites $\left(\mathrm{Fe}^{2+} \rightarrow \mathrm{Mg}, \mathrm{Fe}^{3+} \rightarrow \mathrm{Al}\right)$ and maximal kinking of the double-chain of tetrahedra (the latter being facilitated by $\mathrm{K} \rightarrow \mathrm{Na}$ at the $A$ site).
\end{abstract}

Keywords: potassic-ferrisadanagaite, amphibole, crystal structure, Rietveld, Mössbauer spectroscopy, chemical composition.

SOMMAIRE

Nous avons affiné la structure cristalline de la potassic-ferrisadanagaïte, $\left(\mathrm{K}_{0.66} \mathrm{Na}_{0.32}\right)_{\Sigma 0.98}\left(\mathrm{Ca}_{1.73} \mathrm{Na}_{0.23} \mathrm{Mn}_{0.04}\right)_{\Sigma 2.00}$ $\left(\mathrm{Mg}_{0.55} \mathrm{Fe}^{2+}{ }_{2.16} \mathrm{Mn}_{0.25} \mathrm{Fe}^{3+}{ }_{1.11} \mathrm{Al}_{0.78} \mathrm{Ti}_{0.19}\right)_{\Sigma 5.00}\left(\mathrm{Si}_{5.33} \mathrm{Al}_{2.67}\right)_{\Sigma 8.00} \mathrm{O}_{22}\left[(\mathrm{OH})_{1.21} \mathrm{~F}_{0.41} \mathrm{O}_{0.38}\right]_{\Sigma 2.00}, a$ 9.9309(1), b 18.0949(3), c 5.3681(1) $\AA, \beta 105.19(2)^{\circ}, V 930.9(1) \AA^{3}, C 2 / m, Z=2, D($ calc $)=3.36 \mathrm{~g} / \mathrm{cm}^{3}$, en utilisant la méthode de Rietveld, ce qui a mené aux résidus suivants: $R_{\mathrm{p}}=3.5, R_{\mathrm{B}}=2.6 \%$. Nous nous sommes servis de la spectroscopie de Mössbauer pour déterminer la valeur du rapport $\mathrm{Fe}^{3+} /\left(\mathrm{Fe}^{2+}+\mathrm{Fe}^{3+}\right)$. Les occupants des sites ont été assignés à la lumière de valeurs affinées de la dispersion associée aux sites $A$, $B$ et $C$, la formule chimique dérivée des résultats de l'analyse chimique, et les longueurs de liaison moyennes observées. Le site $T(1)$ est environ à moitié rempli par ${ }^{[4]} \mathrm{Al}$ (2.15 atomes par unité formulaire), et ${ }^{[4]} \mathrm{Al}$ se trouve aussi en proportion importante au site $T(2)$ (0.66 atomes par unité formulaire), d'après la distance $\langle T(2)-\mathrm{O}\rangle$. Cette distribution concorde avec l'absence de liaisons ${ }^{T} \mathrm{Al}-\mathrm{O}-{ }^{T} \mathrm{Al}$ dans la structure (et avec l'absence de $\mathrm{Ca}$ au site $A$ ). En présence d'une telle proportion de ${ }^{T} \mathrm{Al}$ ( $>2$ atomes par unité formulaire), l'articulation du ruban d'octaèdres avec la chaîne double de tétraèdres est assurée par l'incorporation de cations à gros rayon aux sites $M(1), M(2)$ et $M(3)\left(\mathrm{Fe}^{2+} \rightarrow \mathrm{Mg}, \mathrm{Fe}^{3+} \rightarrow \mathrm{Al}\right)$ et une contraction maximum dans la chaîne double de tétraèdres, facilitée par l'incorporation de $\mathrm{K}$ au lieu de $\mathrm{Na}$ au site $A$.

(Traduit par la Rédaction)

Mots-clés: potassic-ferrisadanagaïte, amphibole, structure cristalline, affinement de Rietveld, spectroscopie de Mössbauer, composition chimique.

§E-mailaddresses: evsok@geol.msu.ru,frank_hawthorne@umanitoba.ca 


\section{INTRODUCTION}

The first occurrence of a Si-poor amphibole $(\mathrm{Si}<$ $5.5 \mathrm{apfu}$ : atoms per formula unit) with $\mathrm{Si}=5.27 \mathrm{apfu}$ from alkaline rocks at Wolfe, Ontario, Canada, was reported by Appleyard (1975). Sadanagaite, ideal endmember $\mathrm{Na} \mathrm{Ca}_{2}\left(\mathrm{Fe}^{2+}{ }_{3} \mathrm{Al}_{2}\right)\left(\mathrm{Si}_{5} \mathrm{Al}_{3}\right)_{8} \mathrm{O}_{22}(\mathrm{OH})_{2}$ and its $\mathrm{Mg}$-rich analogue, magnesiosadanagaite, were described from two localities in Japan (Shimazaki et al. 1984, Sawaki 1989). The same authors reported the occurrence of a new Si-poor amphibole with $\mathrm{Fe}^{3+}>{ }^{[6]} \mathrm{Al}$ but did not submit a proposal to the CNMMN of the IMA. The silica-poor (<5.5 Si apfu) calcic amphibole potassic-ferrisadanagaite, ideal end-member $\mathrm{K} \mathrm{Ca}_{2}$ $\left(\mathrm{Fe}^{2+}{ }_{3} \mathrm{Fe}^{3+}\right)\left(\mathrm{Si}_{5} \mathrm{Al}_{3}\right) \mathrm{O}_{22}(\mathrm{OH})_{2}$, has been found recently in a contact zone of the Ilmen alkaline massif, Ilmen Mountains, southern Urals, Russia (Bazhenov et al. 1999; a complete description of the mineral and its geological environment are given in that paper). The behavior of monoclinic amphiboles rich in ${ }^{[4]} \mathrm{Al}$ has been most recently examined by Oberti et al. (1995b) and Hawthorne (1997), who showed that Al-O-Al linkages tend to be avoided except where ${ }^{\mathrm{A}} \mathrm{Ca}$ links to the bridging $\mathrm{O}$ atom. Here, we present results of a crystal-structure investigation of potassic-ferrisadanagaite from the Ilmen massif by means of Rietveld refinement from Xray powder-diffraction data and Mössbauer spectroscopy.

\section{EXPERIMENTAL DetaILS}

A separate of potassic-ferrisadanagaite from the Ilmen alkali massif was available for this work. The grain size of the amphibole was too small for conventional single-crystal four-circle diffractometry, thus we used powder-diffraction to characterize its structure.

\section{Mössbauer spectroscopy}

A sample of potassic-ferrisadanagaite from the Ilmen massif was gently ground in an agate mortar with acetone and mixed with benzophenone to reduce the possibility of preferred orientation of the crystallites. Mössbauer-absorber thickness for the sample was $5 \mathrm{mg}$ $\mathrm{Fe} / \mathrm{cm}^{3}$. The spectrum was collected at room temperature (293 K) on a conventional transmission Mössbauer spectrometer.

The spectrum of potassic-ferrisadanagaite is typical of spectra for amphiboles, and was fitted to two Voigt doublets corresponding to $\mathrm{Fe}^{2+}$ and one Voigt doublet corresponding to $\mathrm{Fe}^{3+}$. Component areas and widths of high- and low-velocity components of each were constrained to be equal, and the Lorentzian linewidth of the Voigt lineshape was fixed at the natural value of 0.195 $\mathrm{mm} / \mathrm{s}$. For $\mathrm{Fe}^{2+}(\mathrm{I})$ and (II), the center shifts are 1.134(5) and $1.11(10) \mathrm{mm} / \mathrm{s}$ (relative to $\alpha-\mathrm{Fe}$ ), the quadrupole splittings are $2.67(1)$ and $2.22(22) \mathrm{mm} / \mathrm{s}$, Gaussian standard deviations are $0.107(6)$ and $0.17(2) \mathrm{mm} / \mathrm{s}$, and the relative areas are 38 and $30 \%$, respectively. $\mathrm{For} \mathrm{Fe}^{3+}$, the center shift is $0.38(9) \mathrm{mm} / \mathrm{s}$ (relative to $\alpha-\mathrm{Fe}$ ), the quadrupole splitting is $0.75(18) \mathrm{mm} / \mathrm{s}$, Gaussian standard deviation is $0.164(2) \mathrm{mm} / \mathrm{s}$, and the relative area is $32 \%$.

\section{Powder diffraction}

Powder-diffraction data were collected on a focusing STOE-STADIP diffractometer equipped with a curved Ge (111) primary monochromator producing monochromatic $\mathrm{MoK} \alpha_{1}$ radiation $(\lambda=0.70926 \AA)$ with a minimum FWHM of $0.08^{\circ}$ according to the procedure of Wölfel (1981). The sample, contained in a quartz capillary, was rotated during exposure to minimize preferred orientation. Diffracted intensities were collected in stepwise overlapping mode of a linear position-sensitive detector with about $5^{\circ}$ acceptance angle and $0.02^{\circ}$ per channel (Wölfel 1983); 2600 data points were collected in the range $2.00<2 \theta<54.98^{\circ}$ (Table 1 ).

Rietveld refinement of the potassic-ferrisadanagaite structure using the atom coordinates of a subsilicic hastingsite (Hawthorne \& Grundy 1977) as a starting model was done with the Wyriet 3.3 program (Schneider 1989). The Pearson VII reflection-profile function was used with reflection profiles considered over a range of six full-width-at-half-maximum (FWHM) and graphical modeling of background. Asymmetry was refined for reflections with $2 \theta$ less than $30^{\circ}$. Occupancies of the $A$ and $M$ sites were refined.

\section{RESULTS}

\section{Mössbauer spectroscopy}

The $\mathrm{Fe}^{2+}$ absorption in the spectrum of potassicferrisadanagaite consists of strongly overlapped doublets (Fig. 1), and the parameters cannot be determined unambiguously. They are typical for $\mathrm{Fe}^{2+}$ occupying one or more of the $M(1), M(2)$ and $M(3)$ sites in the amphibole structure, but specific site-populations for $\mathrm{Fe}^{2+}$ cannot be determined owing to excessive line-overlap.

\begin{tabular}{lclc}
\multicolumn{4}{c}{ TABLE 1. CRYSTALLOGRAPHIC DATA FOR } \\
POTASSIC-FERRISADANAGAITE \\
\hline$a(\AA)$ & $9.9309(1)$ & Bragg reflections & 1160 \\
$b$ & $18.0949(3)$ & Refined parameters & 74 \\
$c$ & $5.3681(1)$ & $R_{\mathrm{p}}(\%)$ & 3.49 \\
$\beta\left({ }^{\circ}\right)$ & $105.19(2)$ & $R_{\mathrm{wg}}(\%)$ & 4.84 \\
$V\left(\AA^{3}\right)$ & $930.9(1)$ & $R_{\mathrm{cxp}}(\%)$ & 2.14 \\
$Z$ & 2 & $R_{\mathrm{B}}(\%)$ & 2.56 \\
Space group & $C 2 / m$ & $R_{\mathrm{F}}(\%)$ & 2.58 \\
$D_{\text {calc }}\left(\mathrm{g} / \mathrm{cm}^{3}\right)$ & 3.36 & $s^{*}$ & 2.26 \\
$2 \theta\left(^{\circ}\right)$-range & $2.00-54.98$ & $D^{*} W^{* *}$ & 0.52 \\
Asymmetry, $2 \theta\left({ }^{\circ}\right)$ & $<30$ & $\sigma_{\mathrm{x}}^{* * *}$ & 2.099 \\
\hline
\end{tabular}

${ }^{*} s=R_{\mathrm{wp}} / R_{\text {exp }} R_{\mathrm{cxp}} ;$ expected value of $R_{\mathrm{rpp}}$

**DWD: Durbin-Watson $d$ statistic (Hill \& Flack 1987)

${ }^{* * *} \sigma_{x}$ : multiplier for the E.S.D. 's (Bérar \& Lelann 1991) 


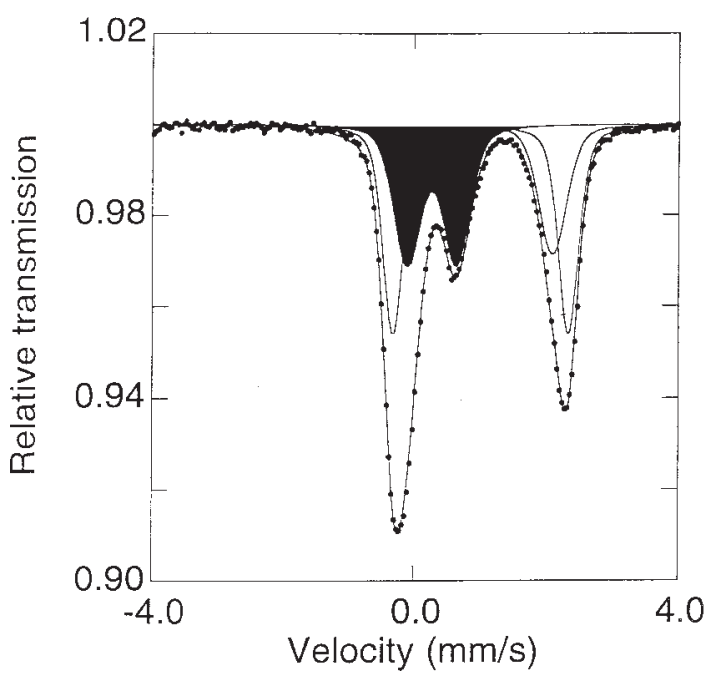

FIG. 1. Room-temperature Mössbauer spectrum of potassicferrisadanagaite, showing two $\mathrm{Fe}^{2+}$ doublets (unshaded) and one $\mathrm{Fe}^{3+}$ doublet (shaded black).

There is no detectable evidence for $\mathrm{Fe}^{2+}$ at the $M(4)$ site. The $\mathrm{Fe}^{3+}$ absorption was fitted to a single quadrupole doublet. $\mathrm{An} \mathrm{Fe}^{3+} / \Sigma \mathrm{Fe}$ ratio of $32 \%$ was determined from the refined area-ratios.

\section{Rietveld refinement}

Final refinement converged to $R_{\mathrm{wp}}=0.048, \mathrm{~s}=R_{\mathrm{wp}}$ $/ R_{\exp }$ (goodness of fit) of 2.26, Durbin-Watson $d$-statistic (Hill \& Flack 1987) DWD of 0.52; all estimated standard deviations have been multiplied by $\sigma_{\mathrm{x}}=2.099$ to correct for serial correlation (Bérar \& Lelann 1991). Atom coordinates and isotropic-displacement factors are given in Table 2, selected interatomic distances are

\begin{tabular}{lcccc}
\multicolumn{5}{c}{ TABLE 2. ATOM COORDINATES AND ISOTROPIC- } \\
DISPLACEMENT FACTORS FOR \\
POTASSIC-FERRISADANAGAITE \\
\hline Site & $x$ & $y$ & $z$ & $B_{\text {iso }}\left(\AA^{2}\right)$ \\
\hline$T(1)$ & $0.2813(2)$ & $0.087(1)$ & $0.3117(1)$ & $0.8(2)$ \\
$T(2)$ & $0.2897(3)$ & $0.174(1)$ & $0.8144(1)$ & $0.7(1)$ \\
$M(1)$ & 0 & $0.091(1)$ & $1 / 2$ & $0.1(2)$ \\
$M(2)$ & 0 & $0.180(1)$ & 0 & $0.2(1)$ \\
$M(3)$ & 0 & 0 & 0 & $0.2(1)$ \\
$M(4)$ & 0 & $0.283(1)$ & $1 / 2$ & $0.1(1)$ \\
$A$ & 0 & $1 / 2$ & 0 & $5.5(6)$ \\
$O(1)$ & $0.1035(3)$ & $0.093(1)$ & $0.2108(1)$ & $0.2(2)$ \\
$\mathrm{O}(2)$ & $0.1184(4)$ & $0.176(1)$ & $0.7380(2)$ & $0.7(3)$ \\
$\mathrm{O}(3)$ & $0.1034(3)$ & 0 & $0.7038(2)$ & $0.9(2)$ \\
$\mathrm{O}(4)$ & $0.3708(3)$ & $0.250(1)$ & $0.7939(1)$ & $0.1(2)$ \\
$\mathrm{O}(5)$ & $0.3500(4)$ & $0.140(1)$ & $0.1161(2)$ & $1.1(1)$ \\
$\mathrm{O}(6)$ & $0.3414(3)$ & $0.118(1)$ & $0.6109(1)$ & $0.4(2)$ \\
$\mathrm{O}(7)$ & $0.3404(3)$ & 0 & $0.2940(1)$ & $0.6(4)$ \\
\hline \multicolumn{5}{c}{}
\end{tabular}

TABLE 3. SELECTED INTERATOMIC DISTANCES ( $($ ) IN POTASSIC-FERRISADANAGAITE

\begin{tabular}{|c|c|c|c|c|}
\hline$T(1)-\mathrm{O}(1)$ & $1.709(3)$ & $M(2)-\mathrm{O}(1)$ & & $2.05(1)$ \\
\hline$T(1)-\mathrm{O}(5)$ & $1.69(1)$ & $M(2)-\mathrm{O}(2)$ & & $2.057(3)$ \\
\hline$T(1)-\mathrm{O}(6)$ & $1.657(8)$ & $M(2)-\mathrm{O}(4)$ & & $1.93(1)$ \\
\hline$T(1)-\mathrm{O}(7)$ & $1.69(1)$ & $\langle M(2)-\mathrm{O}\rangle$ & & 2.01 \\
\hline \multirow[t]{2}{*}{$\langle T(1)-\mathrm{O}\rangle$} & 1.69 & & & \\
\hline & & $M(3)-\mathrm{O}(1)$ & $\times 4$ & $2.13(1)$ \\
\hline$T(2)-\mathrm{O}(2)$ & $1.642(2)$ & $M(3)-\mathrm{O}(3)$ & $\times 2$ & $2.106(2)$ \\
\hline$T(2)-\mathrm{O}(4)$ & $1.61(1)$ & $\langle M(3)-\mathrm{O}\rangle$ & & 2.12 \\
\hline$T(2)-\mathrm{O}(5)$ & $1.688(9)$ & & & \\
\hline$T(2)-\mathrm{O}(6)$ & $1.66(1)$ & $M(4)-\mathrm{O}(2)$ & $\times 2$ & $2.44(2)$ \\
\hline \multirow[t]{2}{*}{$\langle T(2)-\mathrm{O}\rangle$} & 1.65 & $M(4)-\mathrm{O}(4)$ & $\times 2$ & $2.356(6)$ \\
\hline & & $M(4)-\mathrm{O}(5)$ & $\times 2$ & $2.60(1)$ \\
\hline$M(1)-\mathrm{O}(1) \times 2$ & $2.074(2)$ & $M(4)-\mathrm{O}(6)$ & $\times 2$ & $2.55(1)$ \\
\hline$M(1)-\mathrm{O}(2) \times 2$ & $2.14(1)$ & $\langle M(4)-\mathrm{O}\rangle$ & & 2.49 \\
\hline$M(1)-\mathrm{O}(3) \times 2$ & $2.09(1)$ & & & \\
\hline \multirow[t]{2}{*}{$\langle M(1)-\mathrm{O}\rangle$} & 2.10 & $A-\mathrm{O}(5)$ & $\times 4$ & $3.08(1)$ \\
\hline & & $A-\mathrm{O}(6)$ & $\times 4$ & $3.11(1)$ \\
\hline \multirow[t]{2}{*}{$\mathrm{O}(5)-\mathrm{O}(6)-\mathrm{O}(5)$} & $162.7(1)$ & $A-\mathrm{O}(7)$ & $\times 2$ & $2.512(2)$ \\
\hline & & $\langle A-\mathrm{O}\rangle$ & & 2.98 \\
\hline
\end{tabular}

listed In Table 3, and the refined site-scattering values (Hawthorne et al. 1995) are given in Table 4. The refined powder pattern is shown in Figure 2.

\section{Chemical composition}

The chemical composition, taken from Bazhenov et al. (1999), is shown in Table 5, with the $\mathrm{FeO}$ and $\mathrm{Fe}_{2} \mathrm{O}_{3}$ contents modified to reflect the $\mathrm{Fe}^{3+} /\left(\mathrm{Fe}^{2+}+\mathrm{Fe}^{3+}\right) \mathrm{ra}^{-}$ tio determined here by Mössbauer spectroscopy. The unit formula was calculated on the basis of $24(\mathrm{O}, \mathrm{OH}, \mathrm{F})$ under two assumptions: (1) $\mathrm{OH}+\mathrm{F}=2 a p f u$; (2) $\mathrm{OH}+$ $\mathrm{F}=2-2 \mathrm{Ti}$ apfu; the latter calculation assumes that $\mathrm{Ti}$ enters the $M(1)$ site via the substitution ${ }^{M(1)} \mathrm{Ti}^{4+}+2^{\mathrm{O}(3)} \mathrm{O}^{2-}$ $\rightarrow{ }^{M(1)}\left(\mathrm{Mg}+\mathrm{Fe}^{2+}\right)+2^{\mathrm{O}(3)} \mathrm{OH}($ Oberti et al. 1992, Hawthorne et al. 1998). Inspection of the M(1)-O bond lengths in most amphiboles with low $\mathrm{Ti}$ and $\mathrm{OH}+\mathrm{F} \ll$ 2 apfu (e.g., Appendix B4 of Hawthorne 1983) shows that $M(1)-\mathrm{O}(3) \geq\langle M(1)-\mathrm{O}\rangle$. However, in dehydroxylated amphiboles with $\mathrm{OH}+\mathrm{F}<2$ apfu and significant $\mathrm{Ti}^{4+}$ and $\mathrm{Fe}^{3+}$ at $M(1)$ [and $\left.M(3)\right], M(1)-\mathrm{O}(3)<<$ $<M(1)-\mathrm{O}>$. Inspection of Table 3 shows that $M(1)-\mathrm{O}(3)$ $(2.09 \AA)$ is less than $\langle M(1)-\mathrm{O}\rangle(2.10 \AA)$, indicating that potassic-ferrisadanagaite is dehydroxylated and has $\mathrm{Ti}^{4+}$

\begin{tabular}{lllll}
\multicolumn{5}{c}{ TABLE 4. REFINED SITE-SCATTERING VALUES AND ASSIGNED } \\
\multicolumn{5}{c}{ SITE-POPULATIONS FOR POTASSIC-FERRISADANAGAITE } \\
\hline Site & $\begin{array}{l}\text { Site } \\
\text { scattering }\end{array}$ & $\begin{array}{l}\text { Normalized } \\
\text { site scattering* }\end{array}$ & Site populations (apfic) \\
\hline$M(1)$ & 43.1 & 44.1 & $1.30 \mathrm{Fe}^{2+}+0.19 \mathrm{Ti}^{4+}+0.51 \mathrm{Mg}$ & 44.1 \\
$M(2)$ & 41.6 & 42.6 & $0.78 \mathrm{Al}+1.11 \mathrm{Fe}^{3+}+0.11 \mathrm{Fe}^{2+}$ & 41.9 \\
$M(3)$ & 23.9 & 24.5 & $0.70 \mathrm{Fe}^{2+}+0.21 \mathrm{Mn}^{2+}+0.09 \mathrm{Mg}$ & 24.5 \\
$M(4)$ & 35 & 35.8 & $0.04 \mathrm{Mn}^{2+}+1.73 \mathrm{Ca}+0.23 \mathrm{Na}$ & 38.1 \\
$A$ & 16 & 16.4 & $0.32 \mathrm{Na}+0.66 \mathrm{~K}$ & 16.1 \\
\hline
\end{tabular}

* Normalized to the total number of electrons of the $A$-, $B$ - and $C$-group cations in unit formula (2), Table 5. 


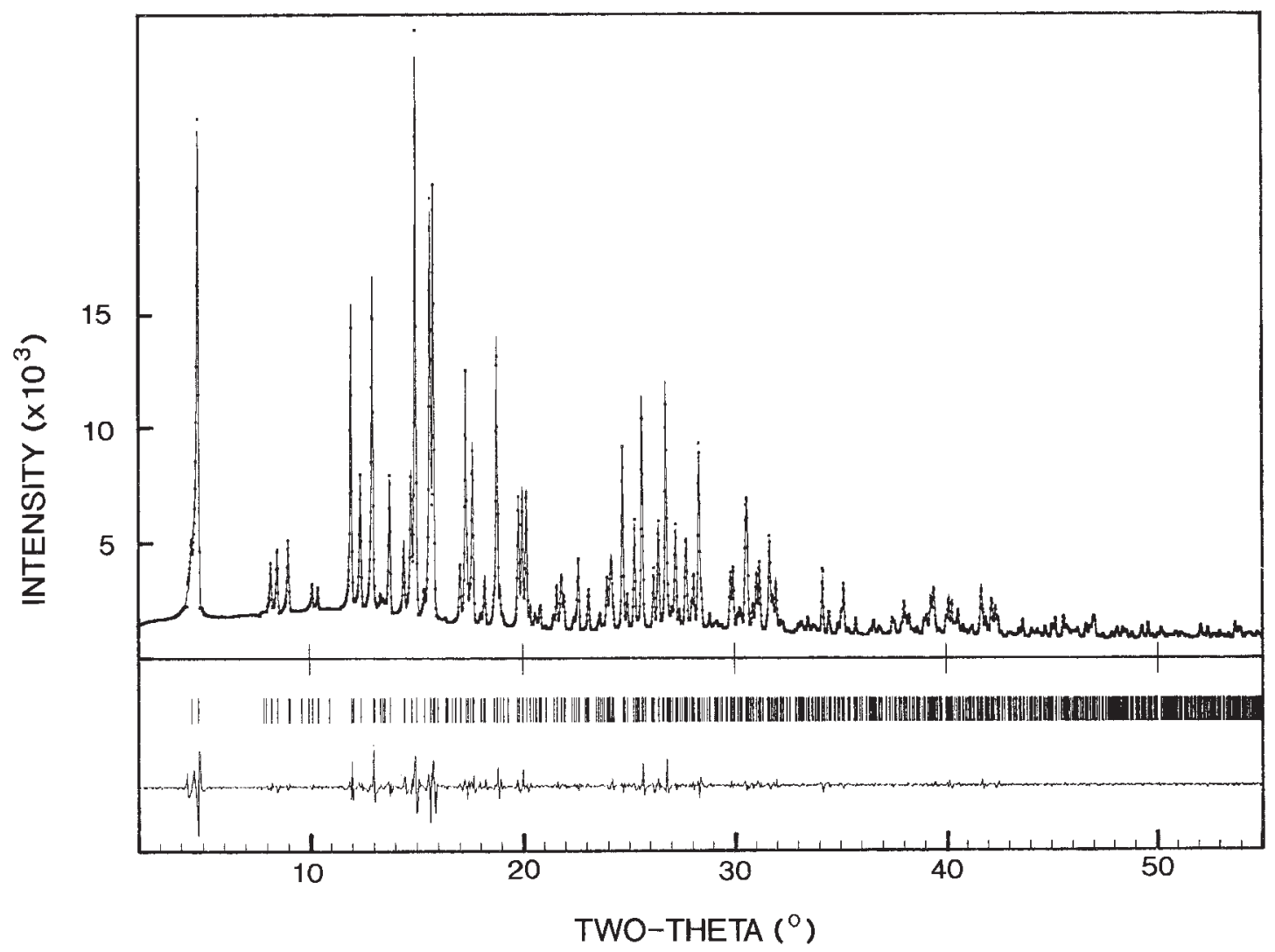

FIG. 2. The refined powder pattern for potassic-ferrisadanagaite; the observed pattern is shown by small circles, the calculated pattern is the continuous line through the small circles, the vertical lines below the pattern show the positions of all the $h k l$ lines, and at the bottom is the difference pattern (observed minus calculated).

at the $M(1)$ site. Thus unit formula (2) of Table 5 is to be preferred over unit formula (1).

\section{DisCUSSION}

\section{Assignment of site populations}

The total scattering from the $C$-, $B$ - and $A$-group sites is 159.6 epfu (electrons per formula unit), and the corresponding number of electrons calculated from unit formulae (1) and (2) (Table 5) are 163.6 and 165.4 epfu, respectively; thus the Rietveld results are slightly underestimating the scattering of the cations. However, we can overcome this problem by renormalizing the refined site-scattering values to the number of epfu calculated from the electron-microprobe analysis. The site populations were assigned using unit-formula (2) of Table 4.

The T sites: $\mathrm{As} \mathrm{Al}(Z=13)$ and $\mathrm{Si}(Z=14)$ have very close scattering factors for X-rays, $\mathrm{Al}$ and $\mathrm{Si}$ can only be assigned to the $T(1)$ and $T(2)$ sites on the basis of the $\langle T(1)-\mathrm{O}\rangle$ and $\langle T(2)-\mathrm{O}\rangle$ bond-lengths. Equations for this procedure are given by Hawthorne (1983) and Oberti et al. (1995a). There is a check on the accuracy of the sum of the ${ }^{[4]} \mathrm{Al}$ site-populations, as this value is derived also by calculating the unit formula from the chemical composition of amphibole. Table 6 lists the predicted site-populations, together with the predicted and observed ${ }^{[4]} \mathrm{Al}$ values for potassic-ferrisadanagaite and amphibole (58) of Hawthorne [1983; $\left(\mathrm{Na}_{0.83} \mathrm{~K}_{0.30}\right)$ $\left(\mathrm{Ca}_{1.74} \mathrm{Na}_{0.12} \mathrm{Fe}_{0.14}\right)\left(\mathrm{Mg}_{1.17} \mathrm{Fe}^{2+}{ }_{2.17} \mathrm{Mn}_{0.04} \mathrm{Al}_{0.58} \mathrm{Fe}^{3+}{ }_{0.79}\right.$ $\left.\left.\mathrm{Ti}_{0.39}\right)\left(\mathrm{Si}_{5.27} \mathrm{Al}_{2.73}\right) \mathrm{O}_{22}(\mathrm{OH})_{2}\right]$. The latter amphibole was initially described as subsilicic hastingsite by Hawthorne \& Grundy (1977), then as subsilicic titanian magnesian hastingsite by Hawthorne (1983); according to the current amphibole-nomenclature scheme (Leake et al. 1997), it is a potassian ferrian sadanagaite. Note that the scheme indicated by Hawthorne (1997) is obeyed approximately: there is a limit of $\sim 2$ apfu on the site populations of $\mathrm{Al}$ at $T(1)$ in order to avoid ${ }^{T} \mathrm{Al}-\mathrm{O}-$ ${ }^{T} \mathrm{Al}$ linkages in the absence of $\mathrm{Ca}$ at the $A$ site.

The $M(1,2,3)$ sites: The total scattering from these sites is 108.6 epfu (electrons per formula unit: 
TABLE 5. CHEMICAL COMPOSITION (wt.\%)* AND FORMULA UNIT (apfu) FOR POTASSIC-FERRISADANAGAITE

\begin{tabular}{|c|c|c|c|c|}
\hline & & & $(1)^{* *}$ & $(2)^{* *}$ \\
\hline $\mathrm{SiO}_{2}$ & 33.24 & $\mathrm{Si}$ & 5.3 & 5.33 \\
\hline $\mathrm{Al}_{2} \mathrm{O}_{2}$ & 18.25 & $\left.{ }^{[4]} \mathrm{A}\right]$ & 2.7 & 2.67 \\
\hline $\mathrm{TiO}_{2}$ & 1.58 & $\Sigma T$ & 8 & 8 \\
\hline${ }^{\dagger} \mathrm{Fe}_{2} \mathrm{O}_{3}$ & 9.25 & & & \\
\hline${ }^{\dagger} \mathrm{FeO}$ & 16.13 & ${ }^{[6]} \mathrm{Al}$ & 0.7 & 0.78 \\
\hline $\mathrm{MnO}$ & 1.83 & $\mathrm{Ti}$ & 0.2 & 0.19 \\
\hline $\mathrm{MgO}$ & 2.31 & $\mathrm{Fe}^{3+}$ & 1.1 & 1.11 \\
\hline $\mathrm{CaO}$ & 10.04 & $\mathrm{Fe}^{2+}$ & 2.2 & 2.16 \\
\hline $\mathrm{Na}_{2} \mathrm{O}$ & 1.78 & $\mathrm{Mn}$ & 0.3 & 0.25 \\
\hline $\mathrm{K}_{2} \mathrm{O}$ & 3.2 & $\mathrm{Mg}$ & $\underline{0.6}$ & $\underline{0.55}$ \\
\hline $\mathrm{H}_{2} \mathrm{O}$ & 1.3 & $\mathbf{\Sigma} C$ & 5 & 5.04 \\
\hline $\mathrm{F}$ & 0.8 & & & \\
\hline $\mathrm{O}=\mathrm{F}$ & $=0.47$ & $\Sigma C-5$ & - & 0 \\
\hline \multirow[t]{9}{*}{ Total } & 99.24 & $\mathrm{Ca}$ & 1.7 & 1.73 \\
\hline & & $\mathrm{Na}$ & $\underline{0.3}$ & $\underline{0.23}$ \\
\hline & & $\Sigma B$ & 2 & 2 \\
\hline & & $\mathrm{Na}$ & 0.3 & 0.32 \\
\hline & & $\mathrm{K}$ & 0.7 & $\underline{0.66}$ \\
\hline & & $\Sigma A$ & 0.9 & 0.98 \\
\hline & & $\mathrm{OH}$ & 1.6 & 1.21 \\
\hline & & $F$ & 0.4 & 0.41 \\
\hline & & 0 & - & 0.38 \\
\hline
\end{tabular}

* Taken from Bazhenov et al. (1999)

** (1) $\mathrm{OH}+\mathrm{F}=2$ apfu, $\mathrm{H}_{2} \mathrm{O}=1.50$ wt.\%; (2) $\mathrm{OH}+\mathrm{F}=$ $2-2$ Ti apfu, $\mathrm{H}_{2} \mathrm{O}=1.13$ wt. $\%$

$\dagger$ from Mössbauer spectroscopy

Hawthorne et al. 1995); the corresponding number of electrons calculated from the unit formula (Table 5) is 111.2. This is reasonable agreement $(\Delta=2.4 \%)$ for Rietveld data, and the difference between the two values is also in accord with the fact that the isotropic-displacement factors for the $M(1), M(2)$ and $M(3)$ sites are anomalously low when compared to analogous singlecrystal values. Presuming that the relative scattering at the $M(1), M(2)$ and $M(3)$ sites is more accurately determined than the actual values, we have renormalized the refined site-scattering values (Table 4) such that their sum is concordant with unit formula (2) of Table 5.

The $M(1)$ and $M(3)$ sites are presumed to be occupied by $\mathrm{Mg}, \mathrm{Fe}^{2+}, \mathrm{Fe}^{3+}$ and $\mathrm{Ti}^{4+}$. The $\mathrm{Ti}^{4+}$ is assigned to the $M(1)$ site (Oberti et al. 1992, Hawthorne et al. 1998) as it participates in the substitution discussed above. This leaves $\mathrm{Mg}$ and $\mathrm{Fe}^{*}\left(=\mathrm{Fe}^{2+}+\mathrm{Mn}^{2+}\right)$, which can be assigned directly from the renormalized site-scattering values; we also assign $\mathrm{Mn}^{2+}$ completely to the $M(3)$ site because of the long $\langle M(3)-\mathrm{O}\rangle$ bond-length, but emphasize that this assignment is somewhat speculative. This leaves the remaining $C$-group cations from the formula unit (Table 5) to be assigned to the $M(2)$ site; the resultant number of electrons at the $M(2)$ site is in close agreement (41.9 versus 42.6 epfu, Table 4) with the refined site-scattering value. The short $M(1)-\mathrm{O}(3)$ distance (Table 3) also suggests the presence of some $\mathrm{Fe}^{3+}$ at the
TABLE 6. ASSIGNED SITE-POPULATIONS FOR ${ }^{[4]}$ AI IN POTASSIC-FERRISADANAGAITE (KSAD) AND AMPHIBOLE (58)

\begin{tabular}{lllll}
\hline & \multicolumn{2}{c}{ KSAD } & \multicolumn{2}{c}{-58} \\
\cline { 2 - 5 } & $\mathrm{H}(1983)^{*}$ & $\mathrm{O}(1995 \mathrm{a})^{* *}$ & $\mathrm{H}(1983)$ & $\mathrm{O}(1995 \mathrm{a})$ \\
\hline${ }^{T(1)} \mathrm{Al}$ & 2.15 & 2.26 & 1.96 & 2.07 \\
${ }^{\mathrm{T}(2)} \mathrm{Al}$ & 0.66 & 0.53 & 0.74 & 0.64 \\
${ }^{T} \mathrm{Al}$ & 2.81 & 2.79 & 2.7 & 2.71 \\
${ }^{T}{ }^{\mathrm{Al}}{ }^{\mathrm{EMP}}$ & 2.67 & 2.67 & 2.73 & 2.73 \\
\hline
\end{tabular}

* equations from Hawthorne (1983)

$\left.{ }^{* *}{ }^{T(2)} \mathrm{Al}=\langle T(2)-\mathrm{O}\rangle-\langle T(2)-\mathrm{O}\rangle\right\rangle_{\mathrm{c}} / 0.02836$, modified after

Oberti et al. (1995b)

$M(1)$ site, but the observed $\langle M(1)-\mathrm{O}\rangle$ distance, $2.103 \AA$ (Table 3), indicates that the amount must be quite small.

\section{Articulation of the octahedron strip} and the double-chain of tetrahedra

Hawthorne \& Grundy $(1973,1977)$ and Robinson $e t$ al. (1973) proposed that the amount of kinking of an amphibole double-chain is a function of the ${ }^{[4]} \mathrm{Al}$ content of the structure. Hawthorne $(1979,1983)$ introduced a simple model for examining dimensional aspects of linkage between the octahedron strip and the doublechain of tetrahedra in the $C 2 / \mathrm{m}$ amphibole structure. Obviously, the details of the linkage between the octahedron strip and the chain of tetrahedra are dependent on the lateral dimensions of the octahedron strip (which is controlled primarily by the mean size of the $C$-group cations) and the double-chain of tetrahedra (which is controlled primarily by the amount of ${ }^{[4]} \mathrm{Al}$ occupancy of the $T$ sites). As the repeat distance of the double-chain of tetrahedra increases, linkage may be maintained by increasing the size of the $C$-group cations and by kinking of the double chain [which may be measured by the $\mathrm{O}(5)-\mathrm{O}(6)-\mathrm{O}(5)$ angle]. In this regard, it is notable that both potassic-ferrisadanagaite and amphibole (58), which have the most aluminous double-chains, also are Fe-rich (and K-rich). Hawthorne (1983) showed that the relative sizes of the octahedron strip and the chain of tetrahedra, as measured by the ratio $3<M-\mathrm{O}>/ 4<T-$ $\mathrm{O}>$, is positively correlated with the $\mathrm{O}(5)-\mathrm{O}(6)-\mathrm{O}(5)$ angle of the double chain (represented as $\sin [\mathrm{O}(5)-$ $\mathrm{O}(6)-\mathrm{O}(5)] / 2)$. This relation is shown in Figure 3, with potassic-ferrisadanagaite and amphibole (58) identified specifically. The latter two amphiboles plot at the bottom end of the trend, in accord with their high ${ }^{[4]} \mathrm{Al}$ values, and show the importance of articulation requirements in affecting details of both stereochemistry and chemical composition.

\section{ACKNOWLEDGEMENTS}

We thank A.G. Bazhenov for supplying us with the sample of potassic-ferrisadanagaite, and Giancarlo Della 


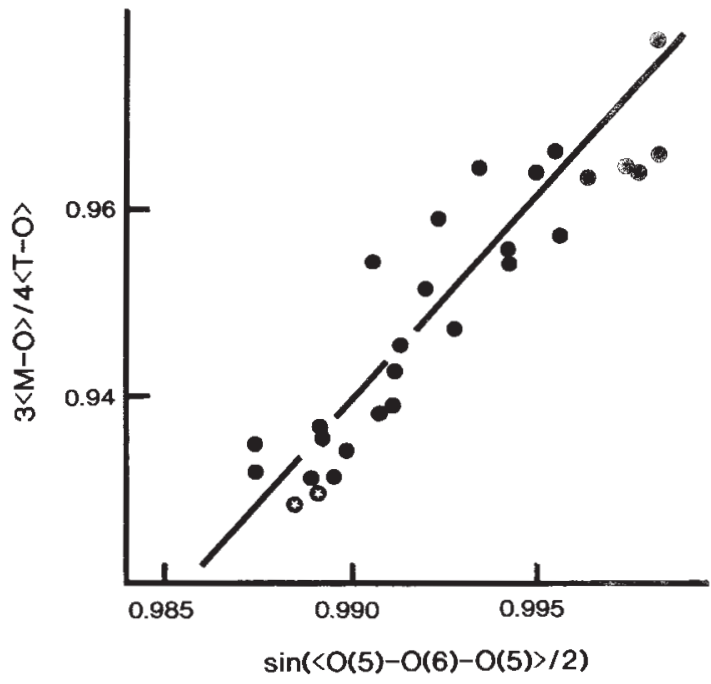

FIG. 3. Variation in relative size of the octahedron strip and the chain of tetrahedra in $C 2 / m$ calcic amphiboles $[3<M-$ $\mathrm{O}\rangle \mid 4\langle T-\mathrm{O}\rangle]$ as a function of the kinking angle $[\mathrm{O}(5)-$ $\mathrm{O}(6)-\mathrm{O}(5)]$ of the double chain of tetrahedra; circles: data of Hawthorne (1983); starred circles: data for potassicferrisadanagaite and amphibole (58); after Hawthorne (1983).

Ventura and Robera Oberti for their comments on the paper. This work was supported by Natural Sciences and Engineering Research Council of Canada Major Equipment, Major Facilities Access and Research Grants to $\mathrm{FCH}$, and by the Russian Fund for Basic Reseach, grant 97-05-64000 to EVS and YuKK.

\section{REFERENCES}

APPLEYARD, E.C. (1975): Silica-poor hastingsitic amphiboles from metasomatic alkaline gneisses at Wolfe, eastern Ontario. Can. Mineral. 13, 342-351.

Bazhenov, A.G., Bazhenova, L.F., Krinova, T.V. \& Khvorov, P.V. (1999): Potassicferrisadanagaite (K,Na) $\mathrm{Ca}_{2}\left(\mathrm{Fe}^{2+}, \mathrm{Mg}\right)_{3}\left(\mathrm{Fe}^{3+}, \mathrm{Al}\right)_{2}\left[\mathrm{Si}_{5} \mathrm{Al}_{3} \mathrm{O}_{22}\right](\mathrm{OH})_{2}$, a new mineral of the amphibole group (the Ilmen Mountains, the Southern Urals). Zap. Vser. Mineral. Obshchest. (in Russ.) (submitted).

BÉRAR, J.F. \& LELANN, P. (1991): E.S.D.'s and estimated probable error obtained in Rietveld refinements with local correlations. J. Appl. Crystallogr. 24, 1-5.

Hawthorne, F.C. (1979): The crystal chemistry of the amphiboles. X. Refinement of the crystal structure of ferroglaucophane. Can. Mineral. 17, 1-10.

(1983): The crystal chemistry of the amphiboles. Can. Mineral. 21, 173-480.
(1997): Short-range order in amphiboles: a bondvalence approach. Can. Mineral. 35, 201-216.

\& GRUNDY, H.D. (1973): The crystal chemistry of the amphiboles. I. Refinement of the crystal structure of ferrotschermakite. Mineral. Mag. 39, 36-48.

$\&$ (1977): The crystal chemistry of the amphiboles. Refinement of the crystal structure of a subsilicic hastingsite. Mineral. Mag. 41, 43-50.

Oberti, R., Zanetti, A. \& Czamanske, G.K. (1998): The role of Ti in hydrogen-deficient amphiboles: sodic-calcic and sodic amphiboles from Coyote Peak, California. Can. Mineral. 36, 1253-1265.

, UnGARETTI, L. \& OBERTI, R. (1995): Site populations in minerals: terminology and presentation of results of crystal-structure refinement. Can. Mineral. 33, 907-911.

HILL, R. \& FLACK, H.D. (1987): The use of the Durbin-Watson $d$ statistic in Rietveld analysis. J. Appl. Crystallogr. 20, 356-361.

LEAKE, B.E. and 21 others (1997): Nomenclature of amphiboles: report of the Subcommittee on Amphiboles of the International Mineralogical Association, Commission on New Minerals and Mineral Names. Can. Mineral. 35, 219246; Am. Mineral. 82, 1019-1037.

Oberti, R., Hawthorne, F.C. Ungaretti, L. \& Cannillo, E. (1995a): ${ }^{[6]} \mathrm{Al}$ disorder in amphiboles from mantle peridotites. Can. Mineral. 33, 867-878.

Ungaretti, L., Cannillo, E. \& Hawthorne, F.C. (1992): The behaviour of Ti in amphiboles. I. Four- and six-coordinate Ti in richterite. Eur. J. Mineral. 3, 425-439.

\& Memmi, I.

(1995b): Temperature-dependent $\mathrm{Al}$ order-disorder in the tetrahedral double-chain of $C 2 / \mathrm{m}$ amphiboles. Eur. J. Mineral. 7, 1049-1063.

Robinson, K., Gibbs, G.V., Ribbe, P.H. \& Hall, M.R. (1973): Cation distribution in three hornblendes. Am. J. Sci. 273A, 522-535.

SAWAKI, T. (1989): Sadanagaite and subsilicic ferroan pargasite from thermally metamorphosed rocks in the Nōgō-Hakusan area, central Japan. Mineral. Mag. 53, 99-106.

SCHNEIDER, J. (1989): Profile refinement on IBM-PC's. IUCr Int. Workshop on the Rietveld method, 71.

ShimazaKi, H., BunNo, M. \& Ozawa, T. (1984): Sadanagaite and magnesio-sadanagaite, new silica- poor members of calcic amphibole from Japan. Am. Mineral. 69, 465-471.

WÖLFEL, E.R. (1981): A new method for quantitative X-ray analysis of multiphase mixtures. J. Appl. Crystallogr. 14, 291-296.

(1983): A novel curved position-sensitive proportional counter for X-ray diffractometry. J. Appl. Crystal$\log r$. 16, 341-348.

Received August 10, 1999, revised manuscript accepted March 25,2000 